\title{
The Relationship between Spiritual Intelligence and Efficacy among Iranian EFL Teachers
}

\author{
Simin Hashemi Marghzar \\ Department of English Language, Islamic Azad University, Qaemshahr Branch, Iran \\ Amir Marzban \\ Department of English Language, Islamic Azad University, Qaemshahr Branch, Iran
}

\begin{abstract}
Owing to the importance of teacher's impact on the students' motivation, achievement, and academic success, this study is an attempt to explore the relationship between EFL (English as a foreign language) teachers' spiritual intelligence and their level of efficacy. To this end, two questionnaires, the Spiritual Intelligence Self-Report Inventory (SIRI-24) (King, 2008), and the ELT Teacher Efficacy Instrument (ELTEI) (Akbari\& Tavassoli, 2014), were distributed among 148 male and female EFL teachers working at different contexts including university, school, and private language institute in Mashad, Quchan, Shirvan, and Qaemshahr, Iran. Pearson product-moment correlation and an independent T-test were used for analysis of the data. The findings of the study revealed that there was a positive significant relationship between teacher spiritual intelligence and teacher efficacy. Moreover, there is a significant difference between male and female teachers regarding their personal meaning production.
\end{abstract}

Index Terms — efficacy, EFL teachers, spiritual intelligence

\section{INTRODUCTION}

The success or failure of each society is dependent on education and teachers lie at the heart of every educational system. Consequently, to have a successful society, teachers should be paid more attention. Wright, Hom, and Sanders (1997) also expressed "more can be done to improve education by improving the effectiveness of teachers than by any other single factor" (p. 63). Regarding the fact that teachers play a major role in guiding and educating students, most researchers have examined the factors which affect teaching. One of the important factors is the teachers' efficacy referring to the teacher's belief about his or her abilities to perform an action successfully (Bandura, 1997). Teacher's efficacy is one of the characteristics of successful teachers (Bandura, 1997) which plays a significant role in schooling (Tschannen-Moran, Woolfolk Hoy, \& Hoy, 1998), and affects on the learners' achievement (Tschannen-Moran, et al., 1998; Yazici, Seyis, \&Altun, 2011), performance (Henson, 2001) and self-efficacy (Anderson, Greene, \& Loewen, 1988). Sense of efficacy affects on teacher's behavior; teachers who have a high sense of efficacy are more patient with student's errors (Ashton \& Webb, 1986), try new methods (Stein \&Wang 1988), have an avid interest in teaching (Guskey, 1984), and dedicate more time to difficult students (Gibson\& Dembo, 1984).

The other factor which affects on teachers' accomplishment is spiritual intelligence. The importance of spiritual intelligence in educational settings and its effects on teachers' effectiveness (George \& Visvam 2013; Rani \& Chahal, 2016), critical thinking (Azizi, \& Azizi, 2015), academic achievement (George \& Visvam 2013), and job satisfaction (Kaur, 2013; Zamani \& Karimi, 2015) have been highlighted. Teachers with high level of spiritual intelligence understand students' feeling, try to support them and teach them how to control their emotions (Rani \& Chahal 2017), as well as how to think critically and creatively (George \& Visvam, 2013).It was also pointed out students with higher level of spiritual intelligence gain benefit from more self-esteem and English language proficiency (Aghaei, Behjat, \& Rostampour, 2014).

Considering the vital role of teachers in any educational systems and the impact of the two above stated construct (self- efficacy and spiritual intelligence) on teachers, most researchers published many books and articles on these issues. In spite of many studies conducted on the relationship between self-efficacy and spiritual intelligence of different participants (nurses, midwives, students, managers and so on), as far as the researchers have investigated only few studies have considered the relationship between the teacher's efficacy and their spiritual intelligence. Furthermore, those few studies (Jafari, Mahmoudi, \& Ziyaei, 2015) have used the questionnaires which are not specific to the context of EFL teaching.

To tackle the above mentioned problems, this study intended to explore the relationship between the teachers' spiritual intelligence and efficacy level using ELT Context-Specific Teacher Efficacy Instrument (Akbari \& Tavassoli, 2014). In keeping with the purpose of the study, the following research questions were raised:

1 - Is there any significant relationship between EFL teacher's spiritual intelligence and their efficacy level?

2- Is there any statistically significant difference between male and female EFL teachers regarding their spiritual intelligence? 


\section{LITERATURE REVIEW}

A brief review of the related studies on the two construct and the significant research data published in this field is presented in the following section.

\section{A. Spiritual Intelligence}

Though emotional intelligence was the fundamental issue at the beginning of the twentieth century, attention was turned to spiritual intelligence by the end of the century. Goleman (as cited in Zohar \& Marshal, 2000) noted emotional intelligence helps the person to identify the situation in which he is, and to behave proper to that situation, while spiritual intelligence helps him to ask if he is satisfied with the situation or should he change the situation to a better one. Gardner (1983) expressed seven types of intelligence (linguistic, musical, logical-mathematical, spatial, bodykinesthetic, interpersonal, and intrapersonal intelligence), but Zohar and Marshal (2000) believe all types of intelligences could be subsumed under the three basic intelligences including intelligence quotient, emotional quotient, and spiritual quotient. Intelligence quotient and emotional quotient exist in computers and animals respectively, while spiritual intelligence is a type of intelligence which is dedicated to human beings (Zohar \& Marshal, 2000). Unlike intelligence quotient which is fixed, emotional intelligence and spiritual intelligence could be improved with training (Singh \& Sinah, 2013). Furthermore, Vaughan (2002) pointed out each person has the capability to develop spiritual intelligence.

With the advent of spiritual intelligence as an ultimate intelligence, most of the publication was dedicated to this topic. One of the great articles was written by Robert Emmons in 2000. In his article, Emmons proposed a model of spiritual intelligence which comprised of five components. King (2008) criticized Emmons' model for failing to discriminate spirituality from religiosity. He further explained the basis of Emmons' model was on religion instead of spirituality. King (2008) defined spiritual intelligence as a set of mental capacities contributing "to the awareness, integration, and adaptive application of the nonmaterial and transcendent aspects of one's existence, leading to such outcomes as deep existential reflection, enhancement of meaning, recognition of a transcendent self, and mastery of spiritual states" (p. 56).

Most researches have been conducted on the concept of spiritual intelligence with different perspectives. Several glaring inconsistencies were considered in the previous reports regarding the difference in the level of spiritual intelligence in male and female participants. Yousefi, Bakhtiarnia, and Robatjazi (2013) reported a higher level of spiritual intelligence in female participants in comparison with their male counterparts, while in Gupta's (2012) report, the males' spiritual intelligence was higher than the females one, and there was no significant difference in Zhaleh and Ghonsooli's (2017) findings in this regard.

\section{B. Teacher Efficacy}

The concept of efficacy rooted in both Rotter's (1966) locus of control and Bandura's (1977) social cognitive theory. Rotter noted two different views including whether the person regards a reward as a result of his action (internal control) or as an event which is not related to his behavior and is dependent on fate and luck (external control). TschannenMoran et al. (1998) pointed out that teachers who believe in their capabilities to help the difficult student are confident that they can control the stimulus of teaching, whereas those who are discouraged about their abilities to overcome the effect of environment on students' outcome have external locus of control. Moreover, they expressed teachers who have a strong sense of efficacy believe they could affect on students' learning.

Bandura (as cited in Tschannen-Moran et al., 1998) refers to teacher efficacy as a type of self-efficacy. He defined perceived self-efficacy as "beliefs in one's capabilities to organize and execute the courses of action required to produce given attainments"( Bandura, 1997, p.3). Bandura (1997) made a distinction between perceived self-efficacy and Rotter's (1966) locus of control. He emphasized that self- efficacy refers to one's judgment about his capabilities to perform an action, while locus of control is the person's belief that the outcome is the consequence of action, in other words, locus of control refers to the causal relationship between action and outcome. He exemplified that a person may believe that an outcome is consequence of a particular action but at the same time is not certain about his abilities to perform that action.

Self-efficacy affects not only on the selection of action but also on the effort that one put into doing something, therefore, those with higher level of efficacy are more active and labor intensive and vice versa (Atay 2007). Bandura (1982) also pointed out the perception of self-efficacy affects on the extent of effort they exert when encountering problems; those with high level of self-efficacy endeavor to solve the problems, whereas those who have a low level of efficacy abandon their attempt.

Significant data published on self-efficacy indicated a positive relationship not only between the teacher's selfefficacy and students' motivation and achievement (Mojavesi \& Poodineh Tamiz, 2012), but also between some components of teacher's self-efficacy and reflective teaching (Babaei \& Abednia, 2016). Moreover, a negative relationship reported between the teachers' self-efficacy and the teacher's burn out (Savaş, Bozgeyik, \& Eser, 2014; Skaalvik \& Skaalvik, 2010), and stress (Vaezi \& Fallah, 2011). There was a discrepancy between the teachers' selfefficacy and the years of teaching experience in the past reports. Some studies reported a positive relationship between 
the two construct (Giallo \& Little, 2003; Hartfield, 2011) while the others rejected such association (Alavinia \& Kurosh, 2012; Rastegar and Memarpour, 2009).

\section{Teacher Self-efficacy and Spiritual Intelligence}

The relationship between spiritual intelligence and self-efficacy has been explored in different contexts. A brief review of the findings is represented in the following section.

Abadi, Jadidi, Iran Nejad, and Pourandish (2016) reported a correlation between spiritual intelligence and its dimensions and self-efficacy of the elderly; self-efficacy was related to some demographic variables including sex, marital status, education, lifestyle, occupation, education and going to the mosque. Considering this relationship, Golchin and Sanjari (2013) revealed a positive relationship between spiritual intelligence and self-efficacy of employees. The same finding was reported by Hassanpour Daman Abad and Talebiannia (2016) among administrates and directors of sport council of East-Azerbaijan province.

\section{Methodology}

\section{A. Participants}

The study used a convenience volunteer sample of 148 teachers (92 females and 56 males) who were teaching English as a foreign language in Mashhad, Quchan, Qaemshahr, Iran. The participants' age ranged from 23 to 56 years old (having at least 2 years of teaching experience). Their academic degree changes from BA to $\mathrm{Ph}$. D (20 of participants had BA degree, while 62 of respondent had MA degree, and 66 participants held a Ph. D).

\section{B. Instruments}

In order to measure the teacher's sense of efficacy, The ELT Teacher Efficacy Instrument (ELTEI) developed by Akbari and Tavassoli (2014) was used. The instrument consisted of 32 items (Cronbach alpha $=.83$ ), which constitute seven components including Efficacy in Classroom Management and Remedial Action (CMR), measured by 8 items, Efficacy in Classroom Assessment and Materials Selection (CAM), measured by 5 items, Efficacy in Skill and Proficiency Adjustment (SPA), measured by 7 items, Efficacy in Teaching and Correcting Language Components (TCL), measured by 5 items, Efficacy in Age Adjustment (AA), measured by 3 items, Efficacy in Social Adaptation (SA), measured by 2 items, Core Efficacy (CE), measured by 2 items. Item responses ranged on a 5-point Likert scale from 1 ("very little") to 5 ("very much").

SIRI-24 developed by King (2008) was used to measure the teacher's spiritual intelligence. The rational for the selection was that its reliability and validity has been established in Iran (KarimiMoonaghi et al, 2013).

SISRI is a 24-item (Cronbach's alpha $=.92$ ) self-report measure of spiritual intelligence. It is consisted of four main constituents including: critical existential thinking (comprised of 7 items), personal meaning production (comprised of 5 items), transcendental awareness (comprised of 7 items), and conscious state expansion (comprised of 5 items). King (2008) reported Cronbach's alpha of .78 for the first (critical existential thinking) and second (personal meaning production) component, Cronbach's alpha of .87 for the third component (transcendental awareness), and Cronbach's alpha of .91 for the last component (conscious state expansion). Item responses ranged on a 5-point Likert scale from 0 ("not at all true of me") to 4 ("completely true of me"). The higher scores are indications of higher levels of spiritual intelligence.

\section{Procedures}

150 questionnaires were distributed among EFL teachers, while only 110 questionnaires were returned; furthermore, 10 questionnaires were discarded since some of the questions left unanswered. Filling out the questionnaire was not obligatory but voluntarily. The participants were informed of the confidentiality of their responses. An electronic version of the questionnaire was also created by the use of Google forms, and was sent through email to 60 teachers. From 60 questionnaires which were sent to participants, only 48 questionnaires were received. Consequently 148 questionnaires were used for the analysis.

\section{Data ANALYSIS AND Results}

As it was stated before, this study aims at exploring the relationship between spiritual intelligence and self-efficacy of EFL teachers. To answer the mentioned research questions, Pearson Product Moment Correlations and an independent sample T-Test were carried out.

Table 1 presents descriptive statistics of EFL teacher spiritual intelligence. Throughout this study, CET stands for critical existential thinking, PMP for personal meaning production, TA for transcendental awareness, CSE for conscious state expansion, SI for spiritual intelligence, CMR for efficacy in classroom management and remedial action, CAM for efficacy in classroom assessment and materials selection, SPA for efficacy in skill and proficiency adjustment, TCL for efficacy in teaching and correcting language components, AA for efficacy in age adjustment, SA for efficacy in social adaptation, CE for core efficacy, and EF for teacher efficacy. 
TABLE 1

DESCRIPTIVE STATISTICS OF EFL TEACHER SPIRITUAL INTELLIGENCE

\begin{tabular}{llllll}
\hline & $\mathrm{N}$ & Minimum & Maximum & Mean & Std. Deviation \\
\hline CET & 148 & 8.00 & 28.00 & 17.6622 & 4.46080 \\
PMP & 148 & 3.00 & 20.00 & 14.1216 & 3.68838 \\
TA & 148 & 10.00 & 28.00 & 18.9595 & 4.03872 \\
CSE & 148 & .00 & 20.00 & 11.9054 & 4.11458 \\
TOTAL SI & 148 & 34.00 & 96.00 & 62.6486 & 13.01013 \\
Valid N (listwise) & 148 & & & & \\
\hline
\end{tabular}

As the Table indicates, among the four constructs of teacher spiritual intelligence, transcendental awareness receives the highest mean $(M=18.95, S D=4.03)$ followed by critical existential thinking $(M=17.66, S D=4.46)$. Table 2 shows descriptive statistics of EFL teacher efficacy.

TABLE 2 DESCRIPTIVE STATISTICS OF EFL TEACHER EFFICACY

\begin{tabular}{llllll}
\hline & $\mathrm{N}$ & Minimum & Maximum & Mean & Std. Deviation \\
\hline CMR & 148 & 16.00 & 39.00 & 30.1351 & 5.00156 \\
CAM & 148 & 7.00 & 25.00 & 19.0270 & 4.05061 \\
SPA & 148 & 15.00 & 31.00 & 23.2027 & 3.56086 \\
TCL & 148 & 12.00 & 25.00 & 18.1216 & 3.51073 \\
AA & 148 & 3.00 & 15.00 & 10.4730 & 2.24501 \\
SA & 148 & 2.00 & 10.00 & 7.7027 & 2.06513 \\
CE & 148 & 4.00 & 10.00 & 7.6757 & 1.60024 \\
TOTALEF & 148 & 80.00 & 153.00 & 116.3378 & 16.87269 \\
Valid N (listwise) & 148 & & & & \\
\hline
\end{tabular}

According to the Table, efficacy in classroom management and remedial action receives the highest mean $(M=30.13$, $S D=5.00)$, followed by efficacy in skill and proficiency adjustment $(M=23.20, S D=3.56)$.

To investigate the relationships among the components of teacher spiritual intelligence and efficacy, multiple correlations were run. The results of Pearson Product Moment correlations are presented in Table 3.

TABLE 3

THE CORRELATION COEFFICIENTS AMONG SPIRITUAL INTELLIGENCE COMPONENT AND EFFICACY SUB FACTORS

\begin{tabular}{|c|c|c|c|c|c|c|c|c|c|c|c|}
\hline & 1 & 2 & 3 & 4 & 5 & 6 & 7 & 8 & 9 & 10 & 11 \\
\hline 1.CET & 1 & & & & & & & & & & \\
\hline 2.PMP & $.503^{* *}$ & 1 & & & & & & & & & \\
\hline 3.TA & $.596^{* *}$ & $.473^{* *}$ & 1 & & & & & & & & \\
\hline 4.CSE & $.381^{* *}$ & $.715^{* *}$ & $.443^{* *}$ & 1 & & & & & & & \\
\hline 5.CMR & -.015 & .114 & $.171^{*}$ & -.003 & 1 & & & & & & \\
\hline 6.CAM & .033 & .138 & .083 & $.172^{*}$ & $.731^{* *}$ & 1 & & & & & \\
\hline 7.SPA & .049 & .099 & .125 & .138 & $.471^{* *}$ & $.446^{* *}$ & 1 & & & & \\
\hline 8.TCL & $.272^{* *}$ & $.484^{* *}$ & $.443^{* *}$ & $.395^{* *}$ & $.466^{* *}$ & $.520^{* *}$ & $.552^{* *}$ & 1 & & & \\
\hline 9.AA & .058 & $.230^{* *}$ & $.200^{*}$ & .160 & $.643^{* *}$ & $.688^{* *}$ & $.449^{* *}$ & $.504^{* *}$ & 1 & & \\
\hline 10.SA & .075 & -.035 & $.284^{* *}$ & .142 & $.302^{* *}$ & $.326^{* *}$ & $.341^{* *}$ & $.392^{* *}$ & $.168^{*}$ & 1 & \\
\hline 11.CE & .026 & .110 & $.240^{* *}$ & .132 & $.551^{* *}$ & $.476^{* *}$ & $.537^{* *}$ & $.659^{* *}$ & $.433^{* *}$ & $.683^{* *}$ & 1 \\
\hline
\end{tabular}

*. Correlation is significant at the 0.05 level (2-tailed)

As indicated in the Table, all of the spiritual intelligence components as well as efficacy components have positive significant relationships with each other. Table 4 shows the correlation coefficient between the two factors of spiritual intelligence and efficacy.

TABLE 4

THE CORRELATION COEFFICIENT BETWEEN SPIRITUAL INTELLIGENCE AND EFFICACY

\begin{tabular}{l|l|l}
\hline & $\mathbf{1}$ & $\mathbf{2}$ \\
\hline 1. Total SI & 1 & $.244^{* *}$ \\
2. Total EF & $.244^{* *}$ & 1 \\
\hline **. Correlation is significant at the 0.01 level (2-tailed).
\end{tabular}

As it can be seen there is a positive significant relationship between teacher spiritual intelligence and teacher efficacy $(r=0.244, p<0.05)$.

To see whether teacher spiritual intelligence differs significantly between genders, an independent-samples $t$ - test was used. Table 6 presents descriptive statistics of teacher spiritual intelligence across males and females. 
TABLE 5

DESCRIPTIVE STATISTICS OF TEACHER SPIRITUAL INTELLIGENCE ACROSS MALES AND FEMALES

\begin{tabular}{llllll}
\hline & Gender & $\mathrm{N}$ & Mean & Std. Deviation & Std. Error Mean \\
\hline CET & Male & 56 & 17.4286 & 4.31849 & .57708 \\
& Female & 92 & 17.8043 & 4.56272 & .47570 \\
\hline PMP & Male & 56 & 12.6786 & 4.65582 & .62216 \\
& Female & 92 & 15.0000 & 2.61021 & .27213 \\
\hline TA & Male & 56 & 18.5000 & 3.56243 & .47605 \\
& Female & 92 & 19.2391 & 4.29763 & .44806 \\
\hline CSE & Male & 56 & 11.2500 & 5.04255 & .67384 \\
& Female & 92 & 12.3043 & 3.39922 & .35439 \\
\hline \multirow{2}{*}{ TOTALSI } & Male & 56 & 59.8571 & 15.23802 & 2.03627 \\
& Female & 92 & 64.3478 & 11.19697 & 1.16737 \\
\hline
\end{tabular}

As the Table indicates, the mean differences of three constructs of spiritual intelligence are different for males and females. In the case of $P M P$, the mean and standard deviation for males are $(M=12.67, S D=4.65)$ and for females are $(M=15.00, S D=2.61)$ and in the case of $T A(M=18.50, S D=3.56)$ for males and $(M=19.23, S D=4.29)$ for females were found. The mean and standard deviation of $C S E$ for males are $(M=11.25, S D=5.04)$ and for females are $(M=12.30$, $S D=3.39)$. However in terms of $C E T$ the mean and standard deviation for males and females are almost the same $(M=$ $17, S D=4.00)$. Concerning spiritual intelligence as a whole $(M=59.85, S D=15.23)$ for males and $(M=64.34, S D=$ 11.19) for females were found. Table 6 shows the results of the independent-samples $t$ - test among the participants of the two groups.

TABLE 6

INDEPENDENT-SAMPLE T-TEST DISPLAYING THE RESULTS OF GENDER DIFFERENCES

\begin{tabular}{llllll}
\hline & T & Df & Sig. (2-tailed) & Mean Difference & Std. Error Difference \\
\hline CET & -.496 & 146 & .621 & -.37578 & .75801 \\
PMP & -3.888 & 146 & .000 & -2.32143 & .59713 \\
TA & -1.080 & 146 & .282 & -.73913 & .68413 \\
CSE & -1.519 & 146 & .131 & -1.05435 & .69430 \\
Total SI & -2.059 & 146 & .041 & -4.49068 & 2.18118 \\
\hline
\end{tabular}

As can be seen, there is a statistically significance between the two groups regarding their $P M P(t=3.88, p<0.05)$. In other words, female EFL teachers have more personal meaning production than their male counterparts. However, no significant difference was found concerning the other spiritual intelligence components in terms of teacher gender.

\section{DISCUSSION AND CONCLUSION}

Based on the results of the study, there was a positive significant relationship between teacher spiritual intelligence and teacher efficacy. The high degree of teacher efficacy increases with the increase of spiritual intelligence. The finding of this study was consistent with Jafari et al. (2015), Abadi et al. (2016), and Hassanpour Daman Abad and Talebiannia (2016). Spiritual intelligence, as it was stated by Singh and Sinah (2013), could be improved by training; therefore, one of the important implications of this finding is that the managers and policy makers can enhance the teachers' efficacy by improving their level of spiritual intelligence. To have a successful educational system and to increase the learners' motivation and achievement, spiritual intelligence and efficacy are two important factors which should be considered while planning the educational programs. Moreover, the result revealed that there was a statistically significance difference between male and female teachers; female EFL teachers have more personal meaning production than their male counterparts. The finding of this study is in line with Yousefi et al. (2013), and Amram and Dryer (2008) who reported a higher level of spiritual intelligence in female participants in comparison with their male counterparts.

\section{SUGgestions FOR FuRTHER RESEARCH}

This study explored the relationship between spiritual intelligence and efficacy in EFL teachers, another study can explore the stated association among teachers in other field of study. The context of this study was limited to Iran, comparative studies may be done in other countries to explore the similarities and differences of the findings.

\section{ACKNOWLEDGMENTS}

The authors wish to thank to all teachers who participated in this study for dedicating their precious time; moreover, we would like to thank the anonymous reviewers and editors of TPLS journal for reading the draft of this article. 


\section{REFERENCES}

[1] Abadi, M.S., A. Jadidi, B. Iran Nejad \& Y. Pourandish. (2016). Is there a relationship between spiritual intelligence and selfefficacy of the elderly. Journal of Fundamental and Applied Sciences 8.2, 1831-1839.

[2] Aghaei, H., F. Behjat \& M. Rostampour. (2014). Investigating the relationship between Iranian high school female students' spiritual intelligence, language proficiency and self-esteem. International Journal of Language and Linguistics 2.6-1, 19-2

[3] Akbari, R. \& K. Tavasoli. (2014). Developing an ELT context-specific teacher efficacy instrument. RELC Journal 45.1, 27-50. doi: $10.1177 / 0033688214523345$.

[4] Alavinia, P. \& S. Kurosh. (2012). On the would-be bonds between emotional intelligence and self-efficacy: The case of Iranian EFL university professors. Theory and Practice in Language Studies 2.5, 956-964.

[5] Amram, Y. \& C. Dryer. (2008). The integrated spiritual Intelligence Scale (ISIS): development and preliminary validation. Paper Presented at the116th Annual Conference of the American Psychological Association Boston, MA.

[6] Anderson, R., M. Greene \& P. Loewen. (1988). Relationships among teachers' and students' thinking skills, sense of efficacy, and student achievement. Alberta Journal of Educational Research 34.2, 148-165.

[7] Ashton, P. T., \& R.B. Web. (1986). Making a difference: Teacher sense of efficacy and student achievement. New York, NY: Longman.

[8] Atay, D. (2007). Beginning teacher efficacy and the practicum in an EFL context. Teacher Development 11, 203-219.

[9] Azizi, M., \& A. Azizi. (2015). Exploring the relationship between EFL teacher's critical thinking and their spiritual intelligence. International Journal of Language Learning and Applied Linguistics World 9.2, 119-130.

[10] Azizi, M., \& M. Zamaniyan. (2013). The relationship between spiritual intelligence and vocabulary learning strategies in EFL learners. Theory and Practice in Language Studies 3.5, 852-858.

[11] Babaei, M., \& A. Abednia. (2016). Reflective teaching and self-study beliefs: Exploring relationships in the context of teaching EFL in Iran. Australian Journal of Teacher Education 41.9, 1-26.

[12] Bandora, A. (1977). Self-efficacy: toward a unifying theory of behavioral change. Psychological Review 84.2, 191-215.

[13] Bandura, A. (1997). Self-efficacy: the exercise of control. New York: W. H. Freeman and Company.

[14] Bandura, A. (1982). Self-efficacy mechanism in human Agency. American Psychologist 37.2, 122-147.

[15] Gardner, H. (1983). Frames of mind: The theory of multiple intelligences. New York: HarperCollins.

[16] George, R. M. \& S. Visvam. (2013). Spiritual intelligence, its correlation with teacher effectiveness and academic achievement-a study. International Journal of Education and Psychological Research 2.2, 106-110.

[17] Giallo, R. \& E. Little. (2003). Classroom behaviour problems: The relationship between preparedness, classroom experiences, and self-efficacy in graduate and student teachers. Australian Journal of Educational \& Developmental Psychology 3, 21-34.

[18] Gibson,S. \& M. Dembo. (1984). Teacher efficacy: A construct validation. Journal of Education Psychology 76, $569-582$.

[19] Golchin, M. \& A. R. Sanjari. (2013). The study of relationship between spiritual quotient with staff self-efficacy: A case study. International Academy of Organizational Behavior management 3, 22-30.

[20] Gupta, G. (2012). Spiritual intelligence and emotional intelligence in relation to self-efficacy and self-regulation among college students. International Journal of Social sciences and Interdisciplinary Research 1.2, 60-69.

[21] Guskey, T. R. (1984). The influence of change in instructional effectiveness upon the affective characteristics of teachers. American Educational Research Journal 21, 245-259.

[22] Hartfield, K. N. (2011). Perceived levels of teacher self efficacy among secondary Arizona agricultural education teachers. Master thesis, Uniersity of Arizona. https://aed.cals.arizona.edu/sites/aed.cals.arizona.edu/files/Hartfield_Thesis.pdf (accessed $14 / 2 / 2017)$.

[23] Hassanpour Daman Abad, A. \& H. Talebiannia. (2016). Relationship between spiritual intelligence (Transcendental consciousness and expanded consciousness mode), self-efficacy with directors and head of the sports general administration of sports and youth east Azerbaijan province. International Journal of Sport Studies 6.7, 445-449.

[24] Henson, R.K. (2001). Teacher self-efficacy: substantive implications and measurement dilemmas. University of North Texas 76203-1337. https://eric.ed.gov/?id=ED452208 (accessed 10/3/2017).

[25] Jafari, S.S., H. M. Mahmoudi \& F. Ziyaei. (2015). Investigating the relationship between Iranian ESP teachers' spiritual intelligence and their self-efficacy. JK Welfare \& Pharmascope Foundation/ International Journal of Review in Life Sciences 5.6, 271-274.

[26] Kaur, M. (2013). Spiritual intelligence of secondary school teachers in relation to their job satisfaction. International Journal of Educational Research and Technology 4.3, 104-109.

[27] King, D. B. (2008). Rethinking claims of spiritual intelligence: a definition, model, and measure. Master thesis, Trent University. file://C:/Users/USER/Desktop/spiritual/thesis.pdf (accessed 15/3/2017).

[28] Mojavesi, A. \& M. Poodineh Tamiz. (2012). The impact of teacher self-efficacy on the students' motivation and achievement. Theory and Practice in Language Studies 2.3, 483-491. doi:10.4304/tpls.2.3.483-491.

[29] Rani, F. \& D. Chahal. (2017). Teacher effectiveness in relation to spiritual intelligence of governmental and public school teachers. Scholarly Research Journal for Humanity Science \& English Language 4. 22, 5317-5325.

[30] Rastegar, M. \& S. Memarpour. (2009). The relationship between emotional intelligence and self-efficacy among EFL teachers. An International Journal of Educational Technology and Applied Linguistics 37.4, 700-707.

[31] Rotter, J. B. (1966). Generalized expectancies for internal versus external control of reinforcement. Psychological Monographs: General and Applied 80.1, 1-28.

[32] Savaş, A.C., Y. Bozgeyik, \& I. Eser. (2014). A study on the relationship between teacher self efficacy and burnout. European Journal of Educational Research 3.4, 159-166.

[33] Singh, M. P. \& J. Sinha. (2013). Impact of spiritual intelligence on quality of life. International Journal of Scientific and Research Publications 3.5, 1-5.

[34] Skaalvik, EM. \& S. Skaalvik (2010). Teacher self-efficacy and teacher burnout: a study of relations. Teaching and Teacher Education 26.4, 1059-69. 
[35] Stein, M. K. \& M.C. Wang. (1988). Teacher development and school improvement: The process of teacher change. Teaching Teacher Education 4, 171-187.

[36] Tschannen-Moran, M., A. Woolfolk Hoy, \& W.K. Hoy. (1998). Teacher efficacy: its meaning and measure. Review of Educational Research 68.2, 202-248.

[37] Vaezi, S. \& N. Fallah. (2011). The relationship between self-efficacy and stress among Iranian EFL teachers. Journal of Language Teaching and Research. 5 .2, 1168-1174. doi:10.4304/j1tr.2.5.1168-1174.

[38] Vaughan, F. (2002). What is spiritual intelligence? Journal of Humanistic Psychology 42.2, 16-33.

[39] Wright, S. P., S.P. Hom \& W.L. Sanders. (1997). Teacher and classroom context effects on student achievement: Implications for teacher evaluation. Journal of Personal Evaluation in Education 11, 57-67.

[40] Yazici, H., S. Seyis \& F. Altun. (2011). Emotional intelligence and self-efficacy beliefs as predictors of academic achievement among high school students. Procedia Social and Behavioral Sciences 15, 2319-2323. doi: 10.1016/j.sbspro.2011.04.100.

[41] Yousefi, M., R. Bakhtiarnia \& M. Robatjazi. (2013). The relationship between spiritual intelligence and quality of translation. International Journal of Language Learning and Applied Linguistics World (IJLLALW) 4.4, 601-612.

[42] Zamani, M. \& F. Karimi. (2015). Relationship between spiritual intelligence and job satisfaction among female high school teachers. Educational research and Reviews 10.6, 739-743. doi: 10.5897/ERR2015.2130.

[43] Zohar, D. (2005). Spiritually intelligent leadership. Leader to Leader 38, 45-51.

[44] Zohar, D. \& I. Marshall. (2000). Connecting with our spiritual intelligence. New York, NY: Bloomsbury.

[45] Zhaleh, K. \& B. Ghonsooli. (2017). Investigating the relationship between spiritual intelligence and burnout among EFL teachers. International Journal of Educational Investigations 4.2, 49-61.

Simin Hashemi Marghzar was born in Quchan. She got her BA and MA in English Translation from Islamic Azad University, Quchan, Iran. She is currently a PhD student in TEFL in Islamic Azad University, Qaemshahr, Iran.

Amir Marzban is an assistant professor of TESOL at Islamic Azad University, Qaemshahr, Iran. His research interests include conversation analysis, L2 reading \& writing, CALL, and teacher education. He has published in both Iranian and International journals and also has presented in many international conferences. 